\title{
Structural variations of silver ethylene complexes supported by boron-protected fluorinated scorpionates and the isolation of a ligand directed silver helix
}

\author{
H. V. Rasika Dias*, Jiang Wu, Xiaoyu Wang, Krishnan Rangan
}

Department of Chemistry and Biochemistry, The University of Texas at Arlington, Arlington, Texas 76019, USA; E-mail: dias@uta.edu

\section{Experimental:}

All manipulations were carried out under an atmosphere of purified nitrogen using standard Schlenk techniques or in a Vacuum Atmosphere single-station drybox equipped with a $-25{ }^{\circ} \mathrm{C}$ refrigerator. Solvents were purchased from commercial sources, purified prior to use. NMR spectra were recorded at $25^{\circ} \mathrm{C}$ on a JEOL Eclipse 500 and JEOL Eclipse 300 spectrometer $\left({ }^{1} \mathrm{H}, 500.16 \mathrm{MHz}\right.$ and $300.53 \mathrm{MHz} ;{ }^{13} \mathrm{C}, 125.78 \mathrm{MHz}$, and $75.59 \mathrm{MHz} ;{ }^{11} \mathrm{~B}, 160.47 \mathrm{MHz}$, and 96.42 MHz; ${ }^{19} \mathrm{~F}, 470.62 \mathrm{MHz}$, and $282.78 \mathrm{MHz}$ ). Proton and carbon chemical shifts are reported in ppm versus $\mathrm{Me}_{4} \mathrm{Si}$. ${ }^{11} \mathrm{~B} \mathrm{NMR}$ values were referenced to external $\mathrm{BF}_{3} \cdot \mathrm{Et}_{2} \mathrm{O} .{ }^{19} \mathrm{~F}$ NMR values were referenced to external $\mathrm{CFCl}_{3}$. Melting points were obtained on a Mel-Temp II apparatus and were not corrected. X-ray data were collected at $100 \mathrm{~K}$ on a Bruker diffractometer with a SmartApex CCD. Silver(I) triflate was purchased from Aldrich, and ethylene gas tank purchased from Matheson. $\left[\mathrm{MeBH}_{3}\right] \mathrm{Li}$ (H. V. R. Dias, X. Wang, Polyhedron 2004, 23, 25332539), $\left[\mathrm{MeB}\left(3-\left(\mathrm{CF}_{3}\right) \mathrm{Pz}\right)_{3}\right] \mathrm{Li}(\mathrm{H}$. V. R. Dias, X. Wang, H. V. K. Diyabalanage, Inorg. Chem. 2005, 44, 7322-7324], and [ $\left.\mathrm{PhBH}_{3}\right] \mathrm{Li}$ (B. Singaram, T. E. Cole, and H. C. Brown, Organomet. 1984, 3, 774-777) were prepared as reported previously.

\section{$\left[\mathrm{MeB}\left(3-\left(\mathrm{CF}_{3}\right) \mathrm{Pz}\right)_{3}\right] \mathrm{Ag}\left(\mathrm{C}_{2} \mathrm{H}_{4}\right)$}

$\left[\mathrm{MeB}\left(3-\left(\mathrm{CF}_{3}\right) \mathrm{Pz}\right)_{3}\right] \mathrm{Li}(0.20 \mathrm{~g}, 0.45 \mathrm{mmol})$ and silver $(\mathrm{I})$ triflate $(0.14 \mathrm{~g}, 0.54 \mathrm{mmol})$ were treated with $30 \mathrm{~mL}$ of dichloromethane saturated with ethylene at $-78^{\circ} \mathrm{C}$ in a light protected Schlenk flask. The reaction mixture allowed to reach room temperature while stirring. Ethylene gas was gently bubbled through the solution for 10 more mins and stirred for additional $10 \mathrm{~h}$. The solvent was removed under a stream of ethylene to obtain $\left.\left[\mathrm{MeB}\left(3-\mathrm{CF}_{3}\right) \mathrm{Pz}\right)_{3}\right] \mathrm{Ag}\left(\mathrm{C}_{2} \mathrm{H}_{4}\right)$ as a white solid $(0.19 \mathrm{~g}, 73 \%)$. X-ray quality crystals were obtained from a hexane solution saturated with ethylene at $-20{ }^{\circ} \mathrm{C}$. M.p. color became yellow around $250{ }^{\circ} \mathrm{C}$ and melts completely at $263-264^{\circ} \mathrm{C}$ 
with decomposition. Anal. Found: $\mathrm{C}, 32.46 ; \mathrm{H}, 2.37 ; \mathrm{N}, 14.41$. Calcd for $\mathrm{C}_{15} \mathrm{H}_{13} \mathrm{AgBF}_{9} \mathrm{~N}_{6}$ : $\mathrm{C}, 31.78$; $\mathrm{H}, 2.31$; N, 14.82\%. ${ }^{1} \mathrm{H}$ NMR $\left(\mathrm{CDCl}_{3}\right): \delta 7.72(3 \mathrm{H}, \mathrm{br}, 5-\mathrm{Pz}), 6.45\left(3 \mathrm{H}, \mathrm{d},{ }^{3} \mathrm{~J}(\mathrm{H}, \mathrm{H})=2.29 \mathrm{~Hz}\right.$, 4$\mathrm{Pz}), 5.47\left(4 \mathrm{H}, \mathrm{s}, \mathrm{C}_{2} \mathrm{H}_{4}\right), 1.07\left(3 \mathrm{H}, \mathrm{s}, \mathrm{CH}_{3}-\mathrm{B}\right) .{ }^{13} \mathrm{C}\left\{{ }^{1} \mathrm{H}\right\} \mathrm{NMR}\left(\mathrm{CDCl}_{3}\right): \delta 143.4\left(\mathrm{q},{ }^{2} \mathrm{~J}(\mathrm{C}, \mathrm{F})=38.4\right.$ $\mathrm{Hz}, \mathrm{Pz}-\mathrm{C} 3$ ), 134.5 (s, Pz-C5), 121.5 (q, ${ }^{1} \mathrm{~J}(\mathrm{C}, \mathrm{F})=268.2 \mathrm{~Hz}, \mathrm{CF}_{3}$ ), 104.0 (br s, $\mathrm{C}_{2} \mathrm{H}_{4}$ ), 103.4 (s, Pz-C4), 5.5 (br s, $\left.\mathrm{CH}_{3}-\mathrm{B}\right) .{ }^{19} \mathrm{~F} \mathrm{NMR}\left(\mathrm{CDCl}_{3}\right): \delta-60.9$ (s). ${ }^{11} \mathrm{~B}$ NMR $\left(\mathrm{CDCl}_{3}\right)$ : $\delta-1.95$ (br s).

\section{[PhB(3-(CF $\left.) P z)_{3}\right] L i$}

$\mathrm{Li}\left[\mathrm{PhBH}_{3}\right](0.40 \mathrm{~g}, 4.09 \mathrm{mmol}) \mathrm{kept}$ at $-25{ }^{\circ} \mathrm{C}$ was added into a pre-cooled Schlenk flask containing 3-( $\left.\mathrm{CF}_{3}\right) \mathrm{PzH}(2.50 \mathrm{~g}, 18.4 \mathrm{mmol})$ inside a $\mathrm{N}_{2}$ glove box. The reaction mixture was brought outside and heated slowly under nitrogen to $150{ }^{\circ} \mathrm{C}$ with stirring. It was kept at this temperature for $6 \mathrm{~h}$ (from time to time, the heat gun was used to melt down the pyrazole collecting on the wall of the flask). The mixture was allowed to cool to room temperature, and the resulting solid was sublimed at $120^{\circ} \mathrm{C}$ under vacuum to remove excess pyrazole to obtain $\left[\mathrm{PhB}\left(3-\left(\mathrm{CF}_{3}\right) \mathrm{Pz}\right)_{3}\right] \mathrm{Li}$ as a white solid $\left(1.87 \mathrm{~g}, 90 \%\right.$, based on $\mathrm{Li}\left[\mathrm{PhBH}_{3}\right]$ used). The product is hygroscopic and forms $\left[\mathrm{PhB}\left(3-\left(\mathrm{CF}_{3}\right) \mathrm{Pz}\right)_{3}\right] \mathrm{Li} \cdot \mathrm{H}_{2} \mathrm{O}$ upon exposure to atmosphere, and even during sample preparation for analyses. Mp 140-145 ${ }^{\circ} \mathrm{C}$. Anal. Found: C, 41.77; H, 2.33; N, 15.70. Calcd for $\mathrm{C}_{18} \mathrm{H}_{13} \mathrm{BF}_{9} \mathrm{LiN}_{6} \mathrm{O}: \mathrm{C}, 41.73 ; \mathrm{H}, 2.53 ; \mathrm{N}, 16.22 \%$. ${ }^{1} \mathrm{H} \mathrm{NMR}\left(\mathrm{CDCl}_{3}\right)$ : $\delta$ 7.37-7.28 $(6 \mathrm{H}, \mathrm{m}$, $P z$ and $P h), 7.03(2 \mathrm{H}, \mathrm{m}, \mathrm{Ph}), 6.44\left(3 \mathrm{H}, \mathrm{d},{ }^{3} \mathrm{~J}(\mathrm{H}, \mathrm{H})=2.06 \mathrm{~Hz}, P z\right), 2.10\left(2 \mathrm{H}, \mathrm{s}, \mathrm{H}_{2} \mathrm{O}\right) .{ }^{13} \mathrm{C}\left\{{ }^{1} \mathrm{H}\right\}$ $\operatorname{NMR}\left(\mathrm{CDCl}_{3}\right): 144.2$ (q, $\left.{ }^{2} \mathrm{~J}(\mathrm{C}, \mathrm{F})=35.8 \mathrm{~Hz}, \mathrm{Pz}-\mathrm{C} 3\right), 137.5$ (s, Pz-C5), 133.5 (s, Ph), (s, Ph), 128.3 (s, Ph), 128.1 (s, Ph), 121.8 (q, $\left.{ }^{1} \mathrm{~J}(\mathrm{C}, \mathrm{F})=268.4 \mathrm{~Hz}, \mathrm{CF}_{3}\right), 103.5$ (s, Pz-C4). ${ }^{19} \mathrm{~F}$ NMR $\left(\mathrm{CDCl}_{3}\right): \delta-61.0\left(\mathrm{~s}, \mathrm{CF}_{3}\right) .{ }^{11} \mathrm{~B} \mathrm{NMR}\left(\mathrm{CDCl}_{3}\right): \delta 0.06$ (br s).

\section{$\left[\mathrm{PhB}\left(3-\left(\mathrm{CF}_{3}\right) \mathrm{Pz}\right)_{3}\right] \mathrm{Ag}\left(\mathrm{C}_{2} \mathrm{H}_{4}\right)$}

Degassed $\mathrm{CH}_{2} \mathrm{Cl}_{2}(30 \mathrm{~mL})$ was added in to a Schlenk flask containing $\left[\mathrm{PhB}\left(3-\left(\mathrm{CF}_{3}\right) \mathrm{Pz}\right)_{3}\right] \mathrm{Li}(0.28$ $\mathrm{g}, 0.56 \mathrm{mmol})$ and silver $(\mathrm{I})$ triflate $(0.17 \mathrm{~g}, 0.66 \mathrm{mmol})$ at $-78{ }^{\circ} \mathrm{C}$ protected from light. Ethylene was bubbled through the solution for $2 \mathrm{~min}$ at $-78{ }^{\circ} \mathrm{C}$, and $10 \mathrm{~min}$ at room temperature, and stirred for $5 \mathrm{~h}$ at room temperature. The resulting mixture was filtered and solvent removed from the filtrate under ethylene atmosphere to obtain the product $\left[\mathrm{PhB}\left(3-\left(\mathrm{CF}_{3}\right) \mathrm{Pz}\right)_{3}\right] \mathrm{Ag}\left(\mathrm{C}_{2} \mathrm{H}_{4}\right)$ as a white solid $(0.28 \mathrm{~g}, 80 \%)$. M.p. sample turns brown around $125^{\circ} \mathrm{C}$ and melts completely at 225 ${ }^{\circ} \mathrm{C}$. Anal. Found: $\mathrm{C}, 38.38 ; \mathrm{H}, 2.48 ; \mathrm{N}, 13.02$. Calcd for $\mathrm{C}_{20} \mathrm{H}_{15} \mathrm{AgBF}_{9} \mathrm{~N}_{6}$ : $\mathrm{C}, 38.19 ; \mathrm{H}, 2.40 ; \mathrm{N}$, 13.36\%. ${ }^{1} \mathrm{H}$ NMR $\left(\mathrm{CDCl}_{3}\right): \delta 7.41(3 \mathrm{H}, \mathrm{br}, 5-\mathrm{Pz}), 7.30(3 \mathrm{H}, \mathrm{m}, \mathrm{Ph}), 6.72(2 \mathrm{H}, \mathrm{br}, \mathrm{Ph}), 6.51$ (3 $\left.\mathrm{H}, \mathrm{d},{ }^{3} \mathrm{~J}(\mathrm{H}, \mathrm{H})=2.41 \mathrm{~Hz}, 4-\mathrm{Pz}\right), 4.72\left(4 \mathrm{H}, \mathrm{s}, \mathrm{C}_{2} \mathrm{H}_{4}\right) \cdot{ }^{13} \mathrm{C}\left\{{ }^{1} \mathrm{H}\right\} \mathrm{NMR}\left(\mathrm{CDCl}_{3}\right): 143.9\left(\mathrm{q},{ }^{2} \mathrm{~J}(\mathrm{C}, \mathrm{F})=\right.$ 36.8 Hz, Pz-C3), 137.9 (s, Pz-C5), 134.0 (s, Ph), 131.0 (s, Ph), 128.7 (s, Ph), 128.0 (s, Ph), $121.4\left(\mathrm{q},{ }^{1} \mathrm{~J}(\mathrm{C}, \mathrm{F})=269.2 \mathrm{~Hz}, \mathrm{CF}_{3}\right), 103.8$ (s, Pz-C4), 101.7 (br s, $\left.\mathrm{C}_{2} \mathrm{H}_{4}\right) .{ }^{19} \mathrm{~F} \mathrm{NMR}\left(\mathrm{CDCl}_{3}\right): \delta-$ $61.8(\mathrm{~s}) .{ }^{11} \mathrm{~B} \mathrm{NMR}\left(\mathrm{CDCl}_{3}\right): \delta 1.42(\mathrm{br} \mathrm{s})$. 


\section{$\left\{\left[\mathrm{PhB}\left(3-\left(\mathrm{CF}_{3}\right) \mathrm{Pz}\right)_{3}\right] \mathrm{Ag}\right\}_{n}$}

Degassed $\mathrm{CH}_{2} \mathrm{Cl}_{2}(30 \mathrm{~mL})$ was added in to a Schlenk flask containing $\left[\mathrm{PhB}\left(3-\left(\mathrm{CF}_{3}\right) \mathrm{Pz}\right)_{3}\right] \mathrm{Li}(0.28$ $\mathrm{g}, 0.56 \mathrm{mmol})$ and silver $(\mathrm{I})$ triflate $(0.17 \mathrm{~g}, 0.66 \mathrm{mmol})$ at $-78{ }^{\circ} \mathrm{C}$ protected from light. The reaction temperature was slowly brought to room temperature and stirred for further $5 \mathrm{~h}$ under $\mathrm{N}_{2}$ atmosphere. The resulting mixture was filtered and solvent removed to obtain the product as a white solid $(80 \%)$. X-ray quality crystals of $\left\{\left[\mathrm{PhB}\left(3-\left(\mathrm{CF}_{3}\right) \mathrm{Pz}\right)_{3}\right] \mathrm{Ag}\right\}_{\mathrm{n}}$ were obtained from a solution of $\mathrm{CH}_{2} \mathrm{Cl}_{2}$ layered with hexane at room temperature in a week. Some decomposed material (black) was also observed. M.p. darkens around $70^{\circ} \mathrm{C}$ and melts completely at $135^{\circ} \mathrm{C}$. ${ }^{1} \mathrm{H}$ NMR $\left(\mathrm{CDCl}_{3}\right)$ : $\delta 7.33(3 \mathrm{H}, \mathrm{br}, 5-P z), 7.28(3 \mathrm{H}, \mathrm{m}, P h), 6.81(2 \mathrm{H}, \mathrm{br}, P h), 6.62\left(3 \mathrm{H}, \mathrm{d},{ }^{3} \mathrm{~J}(\mathrm{H}\right.$, $\mathrm{H})=2.06 \mathrm{~Hz}, 4-P z) .{ }^{13} \mathrm{C}\left\{{ }^{1} \mathrm{H}\right\} \operatorname{NMR}\left(\mathrm{CDCl}_{3}\right): 145.2$ (q, 2J (C, F) = 38.3, Pz-C3), 138.0 (s, Pz-C5), 132.1 (s, Ph), 130.0 (br s, Ph), 128.8 (s, Ph), 128.1 (s, Ph), 125.8 (s, Ph). ${ }^{19} \mathrm{~F} \mathrm{NMR}\left(\mathrm{CDCl}_{3}\right): \delta$ 61.2 (s). ${ }^{11} \mathrm{~B}$ NMR $\left(\mathrm{CDCl}_{3}\right): 2.24$ (br s).

X-ray Data Collection and Structure Determinations. A suitable crystal of each sample covered with a layer of hydrocarbon oil was selected and mounted with Paratone-N oil on a cryo-loop, and immediately placed in the low-temperature nitrogen stream. The X-ray intensity data of $\left[\mathrm{MeB}\left(3-\left(\mathrm{CF}_{3}\right) \mathrm{Pz}\right)_{3}\right] \mathrm{Ag}\left(\mathrm{C}_{2} \mathrm{H}_{4}\right), \quad\left[\mathrm{PhB}\left(3-\left(\mathrm{CF}_{3}\right) \mathrm{Pz}\right)_{3}\right] \mathrm{Ag}\left(\mathrm{C}_{2} \mathrm{H}_{4}\right)$, and $\left\{\left[\mathrm{PhB}\left(3-\left(\mathrm{CF}_{3}\right) \mathrm{Pz}\right)_{3}\right] \mathrm{Ag}\right\}_{\mathrm{n}}$ were measured at 100(2), 163(2), and 100(2) K, respectively, on a Bruker SMART APEX CCD area detector system equipped with a Oxford Cryosystems 700 Series Cryostream cooler, a graphite monochromator, and a Mo $\mathrm{K} \alpha$ fine-focus sealed tube $(\lambda=0.71073 \AA)$. The data frames were integrated with the Bruker SAINT-Plus software package. Data were corrected for absorption effects using the multi-scan technique (SADABS). Structures were solved and refined using Bruker SHELXTL (Version 6.14) software package. Details of the data collection and refinement are in the cif files.

$\left[\mathrm{MeB}\left(3-\left(\mathrm{CF}_{3}\right) \mathrm{Pz}\right)_{3}\right] \mathrm{Ag}\left(\mathrm{C}_{2} \mathrm{H}_{4}\right)$ crystallizes in the Tetragonal crystal system (Figure $\mathrm{S} 1$ ), and $P 4_{3}$ space group. The structure was solved using Direct methods. The structure solution and refinement proceeded smoothly. Hydrogen atoms of ethylene unit were located from the difference map and included, and refined isotropically. Other hydrogens were placed at calculated positions and refined using a riding model. All non-hydrogen atoms were refined anisotropically. The final full-matrix least-squares refinement on $\mathrm{F}^{2}$ with 306 variables converged at $\mathrm{R} 1=1.68 \%$ and $\mathrm{wR} 2=4.25 \%$ for observed data with $\mathrm{I}>2 \sigma(\mathrm{I})$. The goodness-of-fit was 1.043 . 


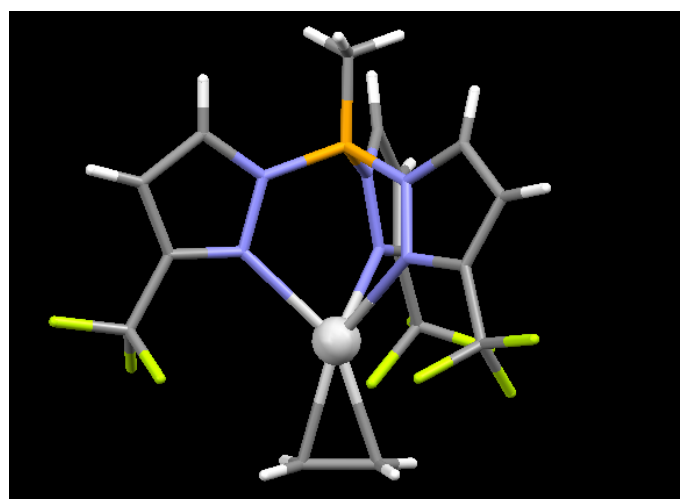

Figure S1. Molecular structure of $\left[\mathrm{MeB}\left(3-\left(\mathrm{CF}_{3}\right) \mathrm{Pz}\right)_{3}\right] \mathrm{Ag}\left(\mathrm{C}_{2} \mathrm{H}_{4}\right)$

$\left[\mathrm{PhB}\left(3-\left(\mathrm{CF}_{3}\right) \mathrm{Pz}\right)_{3}\right] \mathrm{Ag}\left(\mathrm{C}_{2} \mathrm{H}_{4}\right)$ crystallizes in $\mathrm{P}_{2} / \mathrm{c}$ space group (Figure S2). The structure was solved using Direct methods. One of the $\mathrm{CF}_{3}$ groups shows rotational disorder over two positions. This disorder was modeled successfully. All the non-hydrogen atoms (except the three minor occupancy fluorine atoms) were refined anisotropically. Hydrogen atoms of ethylene unit were located from the difference map and included, and refined isotropically. One of these $\mathrm{H}$-atoms shifts considerably during the refinement. Therefore, its position was fixed during the refinement. All the other hydrogen atoms were placed at calculated positions and refined using a riding model. The final full-matrix least-squares refinement on $\mathrm{F}^{2}$ with 361 variables converged at $\mathrm{R} 1=3.58 \%$ and $\mathrm{wR} 2=8.57 \%$ for observed data with $1>2 \sigma(\mathrm{I})$. The goodness-of-fit was 1.084 .

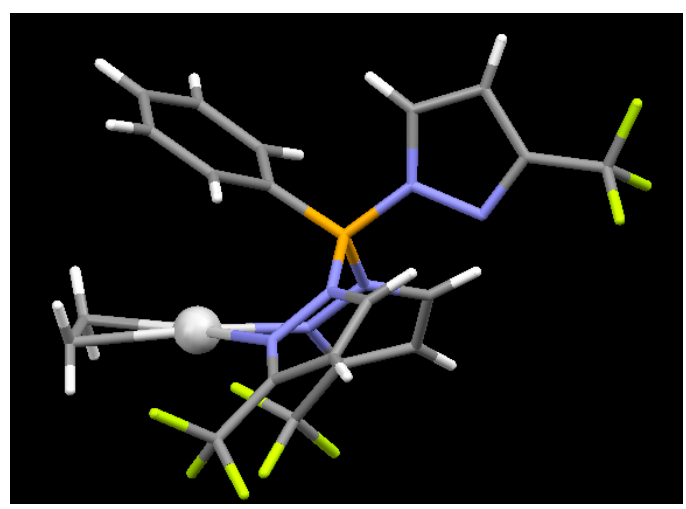

Figure S2. Molecular structure of $\left[\mathrm{MeB}\left(3-\left(\mathrm{CF}_{3}\right) \mathrm{Pz}\right)_{3}\right] \mathrm{Ag}\left(\mathrm{C}_{2} \mathrm{H}_{4}\right)$

$\left\{\left[\mathrm{PhB}\left(3-\left(\mathrm{CF}_{3}\right) \mathrm{Pz}\right)_{3}\right] \mathrm{Ag}\right\}_{\mathrm{n}}$ crystallizes in the Hexagonal $P 6_{5}$ space group. The structure was solved using Direct methods. The B-phenyl group and one of the pyrazolyl groups were disordered over two sites. The $\mathrm{CF}_{3}$ groups on the other two pyrazolyl rings show rotational disorder over two positions. These disorder related issues were solved successfully (see Figure 
S3). The hydrogen atoms were placed at calculated positions and refined using a riding model. All non-hydrogen atoms except the atoms of $\mathrm{CF}_{3}$ moieties were refined anisotropically. The final full-matrix least-squares refinement on $\mathrm{F}^{2}$ with 399 variables converged at $\mathrm{R} 1=6.91 \%$ and $\mathrm{wR} 2$ $=18.79 \%$ for observed data with $\mathrm{I}>2 \sigma(\mathrm{I})$. The goodness-of-fit was 1.022 .
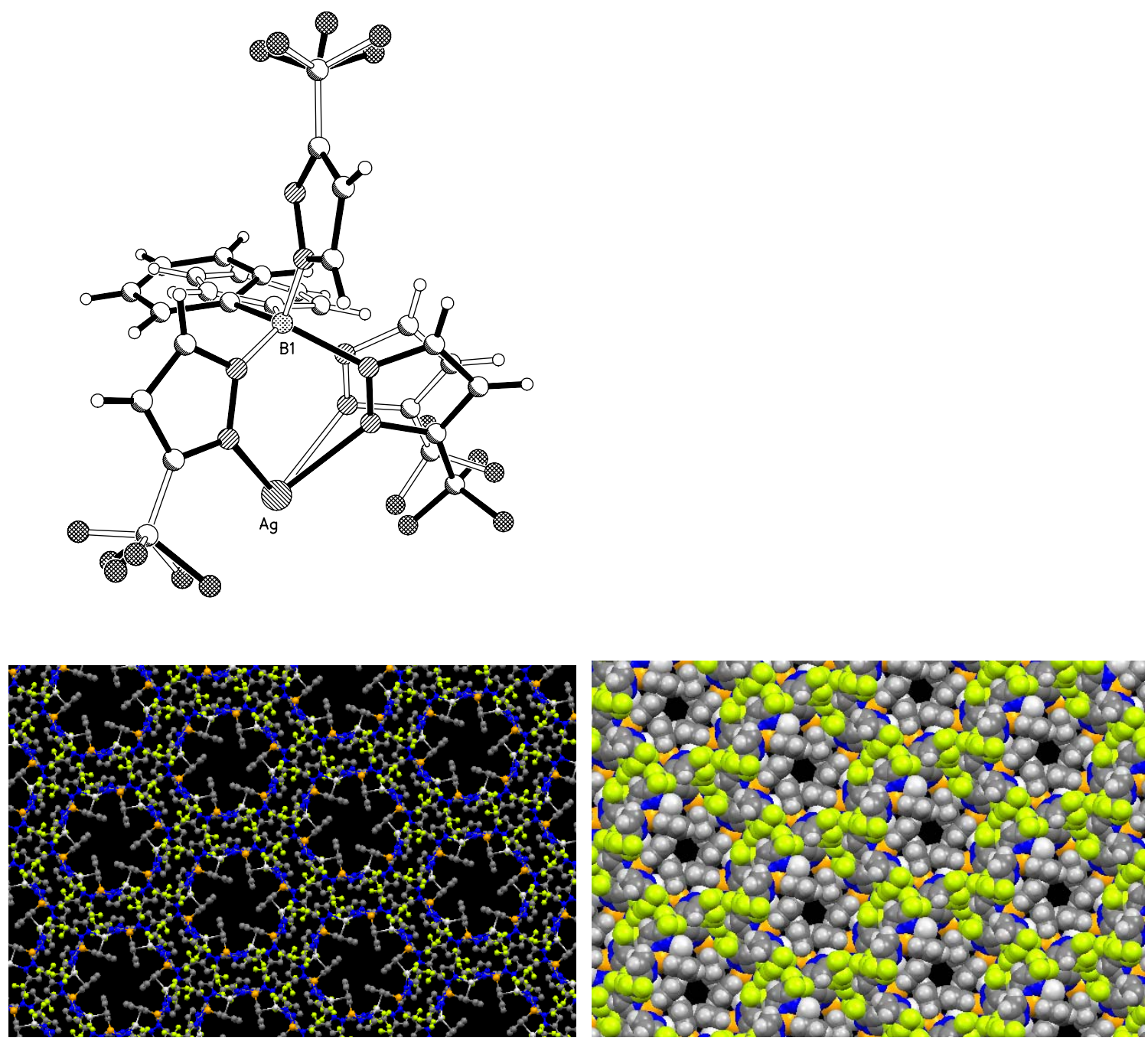

Figure S3. Disorder in $\left\{\left[\mathrm{PhB}\left(3-\left(\mathrm{CF}_{3}\right) \mathrm{Pz}\right)_{3}\right] \mathrm{Ag}\right\}_{n}$ and the packing diagrams showing hexagonal pores 